DOI: $10.18524 / 2307-4558.2021 .35 .237837$

УДК 81’243’372.46:808.5:[378.011.3+378.062.3]:347.176.2:78

ДУЗБ Лариса Іванівна,

кандидат філологічних наук, доцент, доцент кафедри іноземних мов Одеської національної музичної академії імені А. В. Нежданової; вул. Новосельського, 63, м. Одеса, 65023, Україна; тел.: +38 0487269747 ;

e-mail: larisa.duz@gmail.com; ORCID ID: 0000-0003-4507-9018

\title{
ТРЕТІЙ УЧАСНИК ФАХОВИХ КОМУНІКАТИВНИХ СИТУАЦІЙ У МУЗИЧНОМУ ЗАКЛАДІ ВИЩОЇ ОСВІТИ
}

Анотація. Метою статті є демонстрація особливостей фахової комунікації, яка реалізується у музичному закладі вищої освіти за участі іноземних студентів. Об'єкт вивчення - фахова мовленнєва взаємодія музичного педагога та іноземних студентів з різними рівнями володіння мовою навчання. Предмет дослідження - комунікативна роль та характеристики третього учасника фахової мовленнєвої ситуації, у ролі якого діє іноземний студент. У дослідженні застосовано методи спостереження, аналізу та синтезу, зіставлення, узагальнення, а також описовий метод. Результати дослідження: оприявнено реальні комунікативні потреби, які формуються у процесі академічного фахового навчання і мають враховуватися в обгрунтуванні мовних і мовленнєвих компетенцій, потрібних іноземному студентові музичного ЗВО. Типологізовано фахові музично-педагогічні комунікативні ситуації. З'ясовано причини появи ситуації з третім активним учасником. Визначено роль і значення третього комуніканта та необхідні йому мовні компетенції. На підставі вивчення академічних комунікативних ситуації зроблено висновки про фоктори, що зумовлюють успішність фахової взаємодії музичного/вокального педагога й іноземних студентів.

Ключові слова: фахова мовленнєва ситуація, третій учасник комунікації, інтенціональність мовлення, локутивний акт, психофізичний перлокутивний ефект, виконавський апарат музиканта, музичний/вокальний педагог, іноземний студент, музичний заклад вищої освіти.

Постановка проблеми. Реалізація професійно орієнтованого іншомовного навчання, формування комунікативної компетентності іноземних студентів є актуальними завданнями лінгводидактичної практики та її науково-методичного забезпечення. У їхньому вирішенні важливо враховувати специфіку кожного закладу вищої освіти (ЗВО), виявляти особливості конкретних навчально-професійних ситуацій та застосовувати ефективний науковий інструментарій дослідження проблем.

Зв’язок проблеми в попередніми дослідженнями. Вивчення мовленнєвих ситуацій музичного ЗВО у міждисциплінарному дискурсі дали нам підстави виділити основні типи професійної комунікації, суб'єктом якої є іноземний студент [4]. Серед них - загальнопрофесійна ситуація, що реалізується через мовленнєві відносини іноземного студента з комунікантами різних спеціальностей музичної сфери і належить до інтрапрофесійної різнодисциплінарної комунікації. Загальнопрофесійна взаємодія є спільною для всіх студентів музичного ЗВО і передбачає набуття єдиних професійних компетентностей студентами усіх факультетів і спеціальностей.

Номінативно подібним до загальнопрофесійного, але не тотожним є фахове мовленнєве спілкування, що належить до однодисциплінарної комунікації та здійснюється між спеціалістами. Фахова комунікативна ситуація має особливі цілі, базується на спеціальних темах і розгортається у специфічних умовах академічного музичного (вокального, фортепіанного, скрипкового, диригентського тощо) класу, які формують спеціалістів конкретної виконавської галузі. Особливістю фахового спілкування є спеціальна, фахова мова [8, с. 84-85], що забезпечує потреби комунікантів - викладача музичної спеціальності (далі, за прийнятим у музичній педагогічній практиці визначенням, педагог) і студента.

Деякі аспекти взаємодії педагога та іноземного студента - першої та другої осіб фахової комунікації у музичному ЗВО розкриті нами в окремому дослідженні [5]. У представленій роботі аналізуємо причини виокремлення, а також функції та характеристики третього комуніканта в академічній фаховій музично-педагогічній взаємодії.

Аналів останніх досліджень і публікацій. Проблема третього учасника комунікації привертає увагу науковців у зв'язку з дослідженнями у галузі лінгвістики, прагматики, соціолінгвістики. Так, описуючи мікросистему третьої особи як фактор ситуації спілкування, дослідниця фразеології визнає невирішеність (проблеми багатоаспектного вивчення мовленнєвої поведінки з погляду ролі комунікантів (особливо третьої особи у мовленнєвому акті)" [12, с. 38]. На важливості врахування ролі третьої особи мовленнєвої комунікації для пізнання структури різних мов наголошено у дослідженні феномену персонального дейксису та підкреслено “низький рівень теоретичної розробленості проблеми учасників мовленнєвої події) [9, с. 141], що позначається, зокрема, на розумінні (усіх трьох форм займенникової парадигми у лінгвістиці як онтогенетичних прототипів соціальних ролей) [9, с. 138]. Третю особу як суб'єкта комунікації враховано в аналізі проблем мовленнєвого етикету та культури спілкування і при цьому акцентовано на неоднозначній структурі цієї категорії $[13$, с. 155]. У дослідженні кількості учасників як фактора комунікації відзначено, що "традиційне 
розуміння комунікативної ситуації без врахування кількості учасників не дозволяє до кінця виявити особливості мовленнєвої поведінки людини у малих мовленнєвих групах» [11, с. 108]. На необхідність диференціювання адресата і слухача вказує дослідниця категорій метамови та методології психологічної антропології [2, с. 160].

Водночас, незаперечним є широке дослідницьке використання класичної аристотелівської діади оратора і слухача, не зміненої у функціональній моделі Р. Якобсона. Вона досі визнається суб'єктною двоєдністю структури комунікативної ситуації, у яку включені (1) мовець (адресант), 2) слухач (адресат)» [6, с. 157]. Традиційна концепція мовленнєвої взаємодії, що передбачає бінарну структуру відносин між (тим, хто говорить, і тим, хто слухає», заявлена у монографії Т. Г. Винокур [3]. Г. Г. Почепцов розглядає комунікацію як двосторонній процес, де генератор і отримувач інформації наділені активними ролями, що формують цю комунікацію [10, с. 151-152], а треті є особами їхнього впливу [10, с. 452].

Поява нових форм комунікації, а також аналіз вже відомих з урахуванням їхньої контекстуальності вказують на необхідність більшої кількості категорій учасників мовленнєвої події. Здійснюючи аналітичний огляд досліджень проблеми у зв'язку з комп'ютерно-опосередкованими формами комунікації, Є. А. Найман означив найвпливовіші дискурси 1970-1990-х років, реалізовані у програмах Д. Хаймса, І. Гофммана й А. Белла. Істотно, що відмінні дослідницькі напрями етнографічний, соціологічний та соціолінгвістичний відзначалися спільністю предмету та методологічних підходів: були присвячені дослідженню (мови у ситуації) з позицій (соціальної індексальності, контекстності значення та діяльнісної природи мови» [9, с. 133], визнавали основним компонентом мовленнєвої ситуації її учасників і сходилися на думці про вузькість класичної моделі комунікації. Аналіз дослідницьких дискурсів показав, що “врахування ускладнених умов спілкування та взаємозв'язків між ролями учасників мовленнєвої події та їхньою соціальною ідентичністю») [9, с. 133] дає змогу відійти від спрощеної конструкції і розвинути категоріальний апарат, необхідний для опису комунікативних ситуацій.

За допомогою чотирьох категорій пояснював групову комунікативну поведінку Д. Хаймс: Мовець / Відправник - авторитет, що стоїть за повідомленням, Адресант, який озвучує повідомлення, а також Слухач / Аудиторія - людина або група людей, які сприймають повідомлення, й Адресат — той, до кого безпосередньо звернене повідомлення. У цій моделі адресата відділено від слухачів та підкреслено, що в різних мовленнєвих спільнотах люди по-своєму кваліфікують учасників мовленнєвої ситуації [9].

Деталізованіший рольовий поділ категорії Слухач / Аудиторія запропонував I. Гофмман, виокремивши два види: “санкціонованих і несанкціонованих» учасників. До санкціонованих третіх осіб належать присутні, звернення до яких не передбачене. Несанкціонованими, або свідками є випадкові учасники розмови. Важливою особливістю деталізованої структури учасників комунікації є передбачена участь у розмові великої кількості людей.

Згідно з теорією комунікації, найменша зміна, зокрема, у комбінації учасників, трансформує ситуацію, вимагає врахування нових умов у кожний конкретний момент. Стверджується, що у комунікації важливо враховувати як фоксованість, закріпленість ролей за особами комунікації, так і їхню рухливість, змінюваність у певний момент мовленнєвої події. Рольова декомпозиція змінює комунікативну ситуацію і створює новий комунікативний контекст.

Як бачимо, в останній третині XX сторіччя було закладено важливі тенденції сучасного міждисциплінарного дискурсу — відхід від жорсткої конструкції комунікативної події, увагу до прагматичних аспектів комунікації, диференціацію ролей усіх учасників мовленнєвої взаємодії, розробку типології третьої особи у конкретних комунікативних обставинах.

Вище було зауважено брак вітчизняних різногалузевих лінгвістичних досліждень проблеми третього учасника комунікації. Привернемо увагу до її категоріально-типологічної розробленості. Аналіз прагматичного та лінгвосемантичного дискурсу свідчить про нешироке звернення до поняття третього у комунікативній події та різні його тлумачення. В. В. Богданов називає третіми особами тих, що згадуються у комунікації, але не є їхніми учасниками, а також говорить про дотичних учасників на відміну від безпосереднього [1]. Останне трактування підтримала Н. І. Формановська і розрізнила третю особу за комунікативними ролями. Активним учасником спілкування названо присутнього дотичного (вторинного) адресата, до якого безпосередньо не звертаються, але враховують у дискурсі. Спостерігачем означено пасивного учасника спілкування, слухача, який не бере участі у комунікативному процесі, але приймає рішення залежно від почутого [13, с. 176-177]. Очевидно, що в такому трактуванні дотичному адресатові приписується властивість, йому не належна: врахування головними учасниками присутності (третього), насправді, є свідченням їхньої активності. Крім того, прийняття рішення у зв'язку з почутим може бути характеристикою як спостерігача, так і дотичного адресата.

Вартою уваги видається можливість дослідження третьої особи як суб'єкта та об'єкта мовленнєвої взаємодії, представлена Н. В. Федоровою [12]. Типологію комунікативних ситуацій з трьома учасниками, загрунтовану на здійснених у 1980-90-х роках дослідженнях американських соціологів, психологів та соціолінгвістів, пропонує 3. К. Теміргазіна. Нею враховано “конфогурацію учас- 
ників, зміну статусів, відношення між ними» [11, с. 117] та основні характеристики (третьої особи: присутність у момент мовленнєвого акту між двома основними учасниками, неучасть у вербальній комунікації, різні ступені емоційно-психологічної залученості у комунікацію» [11, с. 117]. Вважаємо, що виокремлені ознаки учасників, такі як наявність чи відсутність (внутрішнього коментаря) та (дій, що залишаються у рамках внутрішнього мовлення), а також (інтерес до мовленнєвої події, що виявляється через спостереження за нею» чи (невиявлення інтересу через різні причини - зайнятість власними справами і думками, байдужість тощо» [11, с. 114], можуть правити за типологізуючі щодо текстів художньої прози, котрі є матеріалом дослідниці, проте не є релевантними в прагматичному аналізі реальних ситуацій.

Загалом, доводиться констатувати справедливість твердження про те, що множинність моделей комунікації, зумовлена різноманітністю ситуацій спілкування, робить марними спроби вироблення повної та всеохопної схеми [7, с. 18-19]. Натомість, перспектива бачиться за вивченням певного предмету дослідження в аспекті мовленнєвої взаємодії та подальше уточнення обраної моделі.

Постановка завдання. Метою статті є демонстрація особливостей фахової комунікації, яка реалізується у музичному закладі вищої освіти за участі іноземних студентів. Об'єкт вивчення - фахова мовленнєва взаємодія музичного педагога та іноземних студентів з різними рівнями володіння мовою навчання. Предмет дослідження - комунікативна роль та характеристики третього учасника фахової мовленнєвої ситуації, у ролі якого діє іноземний студент. У дослідженні застосовано методи спостереження, аналізу та синтезу, зіставлення, узагальнення, а також описовий метод.

Виклад основного матеріалу. Заняття зі спеціальності мають комунікативну специфіку у навчальному процесі музичного ЗВО і відрізняються за характером від решти дисциплін. У загальнопрофесійній комунікації, що здійснюється під час лекцій з різних суспільствознавчих і музикознавчих предметів, іноземний студент реалізує переважно інтенцію слухання. Активність його сприйняття та рівень розуміння викладач може з'ясувати, ставлячи питання до всієї аудиторії. Проте, мовлення лектора і його запитання не сприймаються студентами як звернені персонально. Формат лекції не передбачає зміни комунікативних ролей, не створює умов для виявлення іноземного студента як мовця.

На відміну від академічних занять курсу чи групи, що охоплюють багаточисельну аудиторію, урок зі спеціальності є заняттям індивідуальним. Відмінності фахової комунікації від загальнопрофесійної визначаються опозицією “індивідуальне - колективне», з перевагою першого враховувати індивідуально-психологічну своєрідність кожного учня та використовувати особливі способи взаємодії з ним. Допомогти учневі усвідомити власну творчу індивідуальність, створити умови для розкриття її є одним з найважливіших завдань музичного педагога. Формат індивідуального музичного уроку створює умови для ефективної фохової взаємодії педагога та студента і стає основою розвитку міжособистісних відносин. За безпосереднього особистого контакту присутність третьої особи може виступати фактором комунікативного віддалення, сильним подразником, що викликає психічне гальмування, стан скутості учня, коли втрачаються кращі якості його музичного обдарування [5].

Утім, музичне заняття студента віч-на-віч з педагогом є не єдиним різновидом у системі індивідуальних академічних уроків. Деякі з них передбачають присутність концертмейстера, - він чи вона є дозволеною третьою персоною фахової комунікації. Участь концертмейстера у музичному уроці не є вербальною, - у його обов'язки входить музичне акопанування студентові, знання його репертуару, а також спостереження за методикою роботи педагога з кожним учнем. Характерною ознакою концертмейстера як комуніканта $\mathrm{G}$ висока міра інтраперсональної когнітивної та міжособистісної емоційно-психологічної залученості до музично-педагогічної взаємодії. На певних уроках концертмейстер також займається з учнем індивідуально, розучуючи з ним програмні твори. Оскільки роль концертмейстера як фахового комуніканта постійно змінюється - від третьої особи, зацікавленого учасника фохової комунікації, “правиці” педагога, до першої особи зі своїм статусним місцем і роллю, іноземний студент звикає до присутності цієї третьої особи і не сприймає її як сторонню.

У музичній педагогіці практикуються також індивідуальні заняття за присутності студентів, які належать до класу педагога. Присутність таких третіх осіб не передбачена форматом індивідуального уроку, проте відповідає традиції музичної педагогіки. Отже, специфічною ознакою взаємодії педагога та іноземного учня на індивідуальному фаховому уроці є також його широкий суб'єктний комунікативний контекст.

Ядром трьох означенйх різновидів фохової музично-педагогічної комунікації є мікроситуація взаємодії педагога й учня. Ї̈̈ відзначає комунікативна динаміка та зміна головних комунікативних ролей: педагог маніфестує у мовленні актуальні інтенції, студент має відреагувати; негайна подальша реакція педагога продовжує процес фахової взаємодії. Провідні цільові інтенції педагога виражаються констативами, а також директивами, тобто актами спонукання, що мають на меті ініціювати відгук учня, досягнути його відреагування. Вираження перлокутивного ефекту не обов'язково є мовленнєвим у випадку музично-педагогічної взаємодії. Оскільки її метою є вирішення фахових завдань, а саме вироблення музично-виконавських навичок та умінь, від учня очікуються, перш за все, реагування фоховими діями - якістю звуку, виконанням технічної чи художньої задачі тощо. Тому твердження про те, що “власне комунікативна роль слухача полягає у словесній реакції - мовленнєвій дії-відповіді” [3, с. 90], потребує уточнення стосовно випадку фрахової музичної 
комунікації: тут на"вищому рівні процесу сприйняття і розуміння" [3, с. 90] виникає задум та виконання фахової психофозичної дії. Виходячи з теорії мовленнєвих актів можна стверджувати, що перлокутивні ефекти, виражені у психофізичних діях учня, складають мету фахових музичнопедагогічних комунікативних ситуацій. Сенс подібної взаємодії, відповідно до теорії комунікації, полягає “у процесі перекодування вербальної у невербальну і невербальної у вербальну сфери" [12, с. 16]. Тобто, для фахової комунікації істотним є перехід говоріння педагога до дій учня. Це завдання зберігається при фаховій взаємодії педагога й учня в усіх різновидах фохового заняття.

Прагматичні ознаки трьох розглянутих різновидів фахових комунікативних ситуацій зумовлюються кількома факторами: міжособистісним характером і спільністю мети мовленнєвої взаємодії головних комунікантів, мовною однорідністю комунікантів, сталістю статусного розподілу та динамікою ситуативної зміни комунікативних ролей між учасниками.

Індивідуальний фаховий урок - наодинці з педагогом чи у присутності класу - стає особливим випробуванням для іноземних студентів-початківців (далі тажож - учнів), які приступають до академічних занять з музичних спеціальностей, щойно ставши слухачами підготовчого факультету. Вони лише починають вивчати мову навчання, попереду дев'ять місяців освоєння її елементарного курсу, а тим часом уже відбувається їхнє знайомство з педагогом, проходять уроки зі спеціальності, робота над музичною/вокальною програмою тощо. Яким чином відбувається така фбахова взаємодія? За яких умов вона стає успішною?

Першорядне значення має музична освіта та фахова мотивованість іноземного студента, - за цих умов створюються спільні точки фахового порозуміння з українським педагогом. Проте фахове навчання передбачає розвиток умінь, повноцінну фахову взаємодію, - отже, постає завдання подолання мовного бар'єру. Звичайно, працюючи з іноземними студентами, музичний педагог зважає на якість мовних знань та інтепретаційних умінь учня й у зв'язку з ними адаптує власне мовлення. Залежно від рівня мовної компетентності учня педагог може змінити манеру та швидкість мовлення, форму висловлень, проте для нього важливо дотриматися рівня фахових вимог, тобто повноцінно донести зміст мовлення.

Навчаючи іноземних, зокрема китайських, студентів, маючи на меті досягнення ефективності уроків, педагоги випробовують різні способи подолання комунікативних труднощів. Фахова потреба успішного комунікування з іноземними студентами-початківцями спричинилася до появи різновиду індивідуальних академічних музичних/вокальних занять за активної участі третьої особи. На певних уроках педагог може запропонувати роль свого помічника іноземному студентові-старшокурснику, котрий має задовольняти кілька вимог: зокрема, володіти рідною мовою учня або її діалектом, добре знати мову фахового навчання, мати фахові успіхи.

Спілкування з іноземним учнем-початківцем за активної участі іноземця-старшокурсника дозволяє педагогові, ведучи урок, зосереджуватися на змісті мовлення, будувати його, мінімально адаптуючи, досягати інтенціональності мовленнєвих адресувань, не знижуючи рівня фахових вимог у зв'язку з мовним рівнем студента-початківця. У процесі уроку педагог обирає комунікативні ходи, формулює повідомлення. Його комунікативний намір реалізується іллокутивними актами опису, твердження, а також переконання, поради, рекомендації тощо. Маючи на меті викликати відповідну психофізичну інтенцію учня, педагог прагне досягнути якомога більш точного, адекватного розуміння ним своїх спостережень та оцінок щодо кожного конкретного моменту роботи над виконанням музичного чи вокального твору. Спеціальні поняття, сформовані методикою роботи з виконавським апаратом і технікою виконання на певному музичному інструменті та уживані у музично-педагогічній практиці, роз'яснюються описово - виразно, образно, емоційно. Педагоги не викладають теорію співу чи інструментального виконання, - вони вчать розуміти виконавські відчуття у процесі співу, змінювати їх відповідно до звукових та художніх завдань, перетворювати рекомендації у фізичні дії вокаліста чи інструменталіста. Від точної інтерпретації та адекватних реагувань залежить ефективність уроку і фохового просування учня, загалом.

Означена мета фахової взаємодії визначає специфіку завдань активного третього учасника. Для донесення інтенціональності мовлення педагога йому необхідне володіння вокальною та музичною термінологією, добра обізнаність з назвами органів голосового апарату та процесів голосоутворення, а також знання фрахової мови рухів, яка доповнює мовлення педагога під час пояснень. Іноземні студенти вивчають спеціальну термінологію на лінгводидактичних заняттях, крім того неодноразово чують пояснення педагога, звернені до них та до інших учнів класу; вони уміють дублювати жестове пояснення педагога, поєднуючи його з перекладом мовленнєвого ряду. Третій комунікант, так само як друга і решта третіх осіб, приймає інформацію, що йде від педагога різними каналами - вербальними і невербальними. Проте, на відміну від інших, він має здатність до мовного перемикання, яка слугує фактором його рольової трансформації з пасивного присутнього у третього активного учасника фахової комунікації Його завданням $є$ інтерпретувати та донести до учня зміст інформації у взаємодоповненні мовлення, міміки, жестів.

Учень, прийнявши повідомлення педагога та інтерпретацію його третім учасником, має зрозуміти наміри педагога й відреагувати на них. Критеріями відреагування є їхня адекватність інтенціям педагога, виражена у фахових психофізичних діях співу чи гри на музичному інструменті, а також 
невідтермінованість, тобто реалізація безпосередньо у конкретному комунікативному акті, - саме вони стають виявами перлокутивного ефекту комунікативних інтенцій педагога та мовленнєвої діяльності студента-старшокурсника.

Будучи посередником у спілкуванні педагога та учня, іноземець-старшокурсник стає активним учасником комунікації, формує якісно вищий рівень фахової взаємодії, якого неможливо досягнути поза його участю. Таку якість не може забезпечити представник іншої музичної спеціальності чи навіть професійний перекладач, який досконало знає мову та правила перекладу, але не має власного інструментально-виконавського чи, наприклад, вокального досвіду, не володіє умінням накладати правила голосоутворення та голосоведення на роботу власного вокального апарату, не має досвіду формування якості звуку, не здатен трансформувати словесні поради педагога у фахові фізичні дії. Цими навичками та уміннями володіє старшокурсник. Він спроможний сприйняти вербальні поради педагога, поєднати їх з комплексом своїх фохових фозичних відчуттів, сформулювати їх словесно і передати рідною мовою, досягаючи розуміння сказаного і поясненого учнем. Суттєва відмінність студента-посередника мовленнєвої події від професійного перекладача - він є вихованцем певного музичного/вокального класу, перебуває у постійній безпосередній взаємодії зі своїм педагогом, володіє його фаховим словником, знає його методику, уміє накладати пояснення педагога на власні відчуття роботи виконавського апарату та знаходити їм словесне вираження.

Аксіомою музичної педагогіки є врахування якостей виконавського, особливо співочого, апарату, що має індивідуальні особливості будови та функціонування. Педагог пізнає їх у процесі індивідуальних занять з кожним учнем і розробляє конкретні методичні прийоми роботи. Третій учасник, перевагами якого є знання методів свого педагога та засвоєні практичні навички роботи з власним голосовим апаратом за методикою свого педагога, обізнаний зі своїми виконавськими проблемами і способами їхнього подолання, розуміє загальні завдання роботи з голосом, проте не завжди спроможний відчути специфічні проблеми інших вокалістів. Інтерпретувати їх допомагає оволодіння розширеним фоховим словником, а також досвід, набутий під час проходження педагогічної практики на старших курсах.

Іноземний студент-початківець, отримавши базову мовну освіту на підготовчому факультеті та вступивши до музичного ЗВО, продовжує навчатися спеціальності у класі свого педагога та приступає до нового мовного курсу - починає освоювати професійно орієнтовану мову навчання. Від початку цього етапу йому важливо отримати навчальний матеріал та увійти у систему занять, які допоможуть оволодівати не лише гуманітарними та музикознавчими дисциплінами, але й фахом. Іноземець-першокурсник має зрозуміти мету практичних лінгводидактичних занять - вивчення мови як засобу отримання необхідної професійної інформації та фохового спілкування з педагогом. У цьому його можуть переконати лексико-тематичне наповнення лінгводидактичного курсу, пов'язане з професійним напрямом та специфікою фаху, обсяг функціональної граматики, який враховує особливості нефілологічної аудиторії, а такоӝ музичні термінологічні мінімуми, що вводяться системно на розмовній основі. Набуваючи мовних знань, оволодіваючи фоховою мовою та апробуючи мовленнєві уміння на заняттях зі спеціальності двічі-тричі на тиждень, іноземний студент вже на першому-другому курсі почувається впевненіше у спілкуванні з педагогом, може без утруднень інтерпретувати поради педагога. Не маючи потреби у фаховому мовному посередництві, він на третьому-четвертому курсах може сам надавати допомогу педагогові. Таким чином, кожен іноземний студент є потенційним третім активним учасником музично-педагогічної комунікації.

Висновки та перспективи подальших розвідок. На підставі вивчення фахових комунікативних ситуацій музичного ЗВО робимо висновок про їхню зумовленість такими факторами, як характер і спільність мети мовленнєвої взаємодії головних комунікантів, кількість активних учасників комунікації, рівні мовної компетентності іноземних студентів, сталість статусного розподілу та динаміка ситуативної зміни комунікативних ролей між учасниками. З'ясовано, що участь у системі фахової взаємодії мовно некомпетентного іноземного суб'єкта комунікації спричинює появу нової фохавої комунікативної мікроситуації за участю третього активного учасника.

Враховуючи означені вище фоктори, розрізняємо основні види фахових музично-педагогічних комунікативних ситуацій:

1. 3 двома головними комунікантами, один з яких педагог - ініціатор мовленнєвої взаємодії, головний мовець, а другий - студент (український, іноземець-старшокурсник);

2. 3 трьома учасниками, двоє з яких - головні комуніканти при провідній ролі педагога, третім с концертмейстер - зацікавлена фахова особа;

3. 3 трьома учасниками, де головними комунікантами є педагог та іноземний студент-початківець (учень), у ролі третього діє іноземний студент-старшокурсник, фахова мовно компетентна особа;

4. 3 чотирма та більше учасниками, якими, крім двох головних, є концертмейстер, активний третій учасник - іноземний студент-старшокурсник, а також (слухачі-спостерігачі) - іноземні та українські студенти, учні певного музичного чи вокального класу.

Як було простежено, значення третього учасника фахової музично-педагогічної взаємодії, у ролі якого виступає іноземний студент-старшокурсник, обумовлюється його комунікативними функціями, а саме подоланням мовного бар'єру між головними мовцями як різномовними комунікантами, змен- 
шенням комунікативної дистанції між педагогом і студентом-початківцем, скороченням інтерпретаційного шляху у мовленнєвій взаємодії різномовних комунікантів, динамізацією інтерпретаційного процесу і сприянням свідомому цілеспрямованому мовленнєвому та психофбізичному відреагуванню учня, а також інтенціональній скоординованості іллокутивних актів педагога та перлокуції учня.

Виконання ролі третьої активної особи академічної музично-педагогічної комунікації актуалізує фахові та мовленнєві компетенції, пов'язані з виконанням комплексу інтраперсональних психологічних дій, зокрема, таких як сприйняття іншомовного мовленнєвого потоку, інтерпретація його у зв'язку з досвідом власних психофізичних відчуттів та фахових умінь і навичок, перекодування психофізичних реагувань у мовленнєві, невідтерміноване вираження почутого і самопізнаного рідною мовою та мовою навчання.

Характеристики, що відзначають третього активного учасника фахової музично-педагогічної комунікації, - володіння мовою навчання, здатність до мовного перемикання, знання вокальної та музичної термінології, вузькофахових понять, фахової мови рухів. Мають значення також наявність досвіду навчання у класі свого педагога, фахова успішність.

Вважасмо, що дослідження прагматичних аспектів фохової музично-педагогічної комунікації оприявнює реальні комунікативні потреби іноземного студента, які виникають у процесі навчання. Результати аналізу фахової комунікації мають враховуватися в обгрунтуванні необхідних мовних та мовленнєвих компетенцій іноземного студента музичного закладу вищої освіти.

\section{Лime ратура}

1. Богданов В. В. Речевое общение : Прагматические и семантические аспекты. Ленинград : Изд-во СПбГУ, 1990. $88 \mathrm{c.}$

2. Верхотурова Т. Л. Наблюдатель как методологическая категория лингвистического и общенаучного дискурса. Вестник Новосибирского гос. университета. Лингвистика и межкультурная комлуникачия. Новосибирск, 2006. T. 4. Вып. 2. С. 155-162.

3. Винокур Т. Г. Говорящий и слушающий. Варианты речевого поведения. Москва : Либроком, 2009. 242 с.

4. Дузь Л. Професійні мовленнєві ситуації як фактор подолання посттравматичного стресового розладу (лінгводидактичний дискурс). European Humanities Studies : State and society. 2020. Issue 4. C. 158-172.

5. Дузь Л. І. Суб'єктні аспекти фахової комунікації педагога та іноземного студента музичного ЗВО. Науковий вісник Міжнародного гуманітарного університету. Філологія. Одеса, 2020. № 46. Т. 1. С. 133-137.

6. Жеребило Т. В. Словарь лингвистических терминов. 5-е изд., испр. и доп. Назрань : Пилигрим, 2010. 486 с.

7. Карасик В. И. Язык социального статуса. Москва : Гнозис, 2002. 333 с.

8. Масенко Л. Т. Нариси з соціолінгвістики. Київ : Києво-Могилянська академія, 2010. 242 с.

9. Найман Е. А. Проблема участников речевого события в современной прагматике. Вестник Толского государственного университета. Философия. Сочиология. Политология, 2017. № 40. С. 132-143.

10. Почепцов Г. Г. Теория коммуникации. Москва : Реффл-бук, 2001. 656 с.

11. Темиргазина 3. К. Количество участников как фактор коммуникативной ситуации : типология ситуаций с тремя участниками. Вестник РУДН. Теория языка. Семиотика. Семантика. Москва, 2019. Т. 10. № 1. С. $108-120$.

12. Фёдорова Н. В. Белорусские фразеологизмы со значением характеристик речевого поведения и роли третьего лица в ситуации общения. Вісник Донещького начіонального університету. Сер. Б : Гуманітарні науки. Донецьк, 2012. Вип. 1-2. С. 37-45.

13. Формановская Н. И. Речевое взаимодействие : коммуникация и прагматика. Москва : Икар, 2007. 480 с.

\section{References}

1. Bogdanov, V. V. (1990), Speech communication: Pragmatic and semantic aspects [Rechevoe obshchenie : Pragmaticheskie $i$ semanticheskie aspekty]. St. Petersburg State University Press, Leningrad, 88 p.

2. Verkhoturova,T. L. (2006), "Observer as a methodological category in linguistic and scientific discourse", NSU Vestnik. Series : Linguistics and Intercultural Communication ["Nablyudatel' kak metodologicheskaya kategoriya lingvisticheskogo i obshchenauchnogo diskursa", Vestnik NGU, Lingvistika i mezhkul'turnaya kommunikatsiya], Novosibirsk, vol. 4 , issue 2 , pp. 155-162.

3. Vinokur, T. G. (2009), The Speaker and the Listener. Variants of Speech Behavior [Govoryashchiy $i$ slushayushchiy. Varianty rechevogo povedeniya], Librokom Publishing house, Moscow, $242 \mathrm{p}$.

4. Duz, L. (2020), "Professional speech situations as a factor in prevention of post-traumatic stress disorder (Linguodidactics discourse)", European Humanities Studies : State and Society ["Profesiyni movlennievi sytuatsii yak faktor podolannya posttravmatychnoho stresovoho rozladu (linhvodydaktychnyi dyskurs)"], issue 4, pp. 158-172.

5. Duz, L. (2020), "Subjective aspects of the profession-themed teacher - student communication at a higher music education institution", International Humanitarian University Herald. Philology ["Subyektni aspekty fakhovoi komunikatsii pedahoha ta inozemnoho studenta muzychnoho ZVO", Naukovyi visnyk Mizhnarodnoho humanitarnoho universytetu], Odessa, vol. 46, issue 1, pp. 133-137.

6. Zherebilo, T. V. (2010), Dictionary of linguistic terms, $5^{\text {th }}$ ed. [Slovar' lingvisticheskikh terminov, 5-e izd.], Piligrim Publishing house, Nazran', 486 p.

7. Karasik, V. I. (2004), The language of social status [Yazyk sotsial'nogo statusa], Gnosis Publishing house, Moscow, $336 \mathrm{p}$.

8. Masenko, L. T. (2010), Essays on sociolinguistics [Narysy z sotsiolinhvistyky], National University of Kyiv Mohyla Academy, Kyiv, 242 p. 
9. Nayman, E. A. (2017), "The Problem of Participants in a Speech Event in Modern Pragmatics", Tomsk State University Journal of Philosophy, Sociology and Political Science ["Problema uchastnikov rechevogo sobytiya v sovremennoy pragmatike", Vestnik Tomskogo gosudarstvennogo universiteta, Filosofiya, Sociologiya, Politologiya], Tomsk, vol. 40, pp. $132-144$. $656 \mathrm{p}$.

10. Pocheptsov, G. G. (2001), Communication theory [Teoriya kommunikatsii], Refl-book Publishing house, Moscow,

11. Temirgazina, Z. K. (2019), "The Number of Participants as a Communicative Situation Factor: a Typology of Situations with Three Participants", RUDN Journal of Language Studies, Semiotics and Semantics ["Kolichestvo uchastnikov kak faktor kommunikativnoy situatsii : tipologiya situatsiy s tremya uchastnikami", Vestnik RUDN. Teoriya yazy$k a$, Semiotika, Semantika], Moscow, vol. 10, issue 1, pp. 108-120.

12. Fedorova, N. V. (2012), "Belarusian phraseology with the meaning of the characteristics of speech behavior and the role of the third person in the communication situation", Bulletin of Donetsk National University, Series B : The Humanities ["Belorusskie frazeologizmy so znacheniem kharakteristik rechevogo povedeniya i roli tret'ego lica v situatsii obshcheniya", Visnyk Donets'kogo natsional'nogo universytetu, B : Humanitarni nauky, vol. 1-2, pp. 37-45.

13. Formanovskaya, N. I. (2007), Speech interaction : communication and pragmatics [Rechevoe vaaimodejstvie : kommunikaciya i pragmatika], IKAR Publishing house, Moscow, 480 p.

Larisa I. DUZ,

PhD (Philology), Associate Professor, Associate Professor at the Foreign Language Department, Odessa National A. V. Nezhdanova Academy of Music; 63 Novosel'skogo str., Odessa, 650023, Ukraine;

tel.: +380487269747; e-mail: larisa.duz@gmail.com; ORCID ID: 0000-0003-4507-9018

\section{THE THIRD PARTICIPANT IN THE PROFESSION-SPECIALIZED COMMUNICATION WITHIN A MUSIC HIGHER EDUCATION INSTITUTION}

Summary. The following paper aims at demonstrating special features of profession-centered communication being performed in a music higher education institution with the participation of foreign students. The object of this study is the profession-centered speech interaction of the music/vocal pedagogue with foreign students who possess different levels of language knowledge. The subject of the study is the third communicant, most often a foreign student, his/her role and characteristics. As methods the study uses observation, analysis and synthesis, comparison, generalization and description. The results are as follows. The study identifies real-life communication needs that are being formed in the process of profession-specialized studies and therefore have to be considered in the founding of language and speech competences of a foreign student; it also establishes types of professional communication in a music higher education institution. Further, the study clarifies the reasons that lead to a situation that requires the participation of a third person; finally, it defines the role and the meaning of the third participant as well as the language competence needed by him/her. The analysis of academic communication serves as a foundation for the conclusion on factors which define the success of professional interactions between the music / vocal pedagogue and the foreign students.

Key words: professional speech situation, third participant in communication, intentionality of speech, locutionary act, psychophysical perlocutionary effect, music / vocal pedagogue, foreign student, music higher education institution.

Статтю отримано 15.04.2021 p.

DOI: $10.18524 / 2307-4558.2021 .35 .237790$

УДК $811.161 .2 \div 42: 82-1 “ 1990 / 2009 ”$

СЩЕНКО Тетяна Анатоліївна,

кандидат філологічних наук, доцент, завідувачка кафедри українознавства Львівського національного медичного університету імені Данила Галицького, вул. Шимзерів, буд. За, м. Львів, 79010, Україна;

тел.: +380 (32) 2786446; e-mail: teua.lviv@gmail.com; ORCID ID: 0000-0002-3624-5072

\section{КОЛЕКТИВНИЙ АДРЕСАНТ ПОЕТИЧНОГО ТЕКСТУ: КОМУНІКАТИВНО- ПРАГМАТИЧНИЙ АСПЕКТ}

Анотація. Мета статті - опис лінгвоперсонологійних виявів колективного адресанта української поевії кінця XX століття як літературно-мовного феномена, окреслення динаміки зрушень та стильові тенденції іміджу митців постколоніального українського дискурсу. Джерельною базою розвідки слугують поетичні словесні цілі, з яких у спосіб точної і повної інвентаризації здійснено вибірку одиниць (метафор, епітетів, перифраз, оксюморонів тощо), що маніфестують текстову категорію (колективний адресант). Об'єктом вивчення є український поетичний дискурс постколоніальної епохи та його складники (колективний адресант↔текст↔адресат), а предметом - художні образи української поезії 1990-х років як виразники колективного адресанта "девятдесятників». Джерельною базою обрано віршовані твори сучасних українських поетів В. Виноградова, Р. Скиби, І. Павлюка, Л. Мельник, М. Кіяновської, 